\title{
ARTILLERY PEAK ORIENTATION STUDY, MOHAVE COUNTY, ARIZONA
}

K. P. Puchlik

D. L. Leach

D. Cazes

March 12, 1979

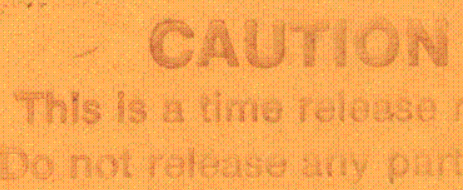

publicakon berory

Work performed under the auspices of the U.S. Department of Energy by the UCLLL under contract number W-7405-ENG-48.

\section{近 \\ I-AWRENCE \\ LIVERMORE IABORATORY}

University of California/Livermore

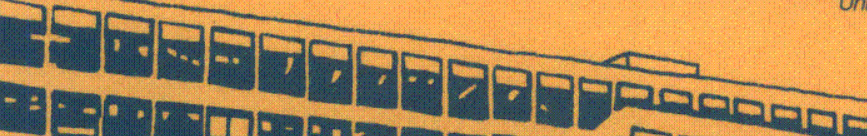

T)

.

$+7$

in
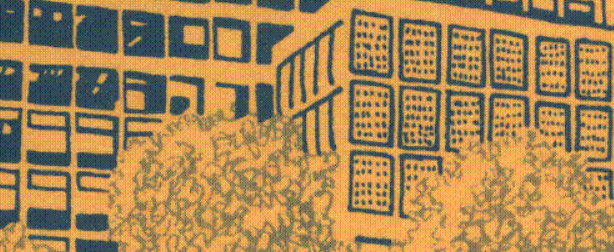

10
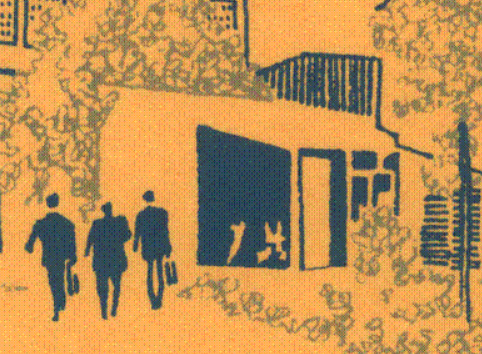

诓

s. 
NOTICE

"This report was prepared as an account of work sponsored by the United States Government. Neither the United States nor the United States Department of Energy, nor any of their employees, nor any of their contractors, subcontractors, or their employees, makes any warranty, express or implied, or assumes any legal liability or responsibility for the accuracy, completeness or usefulness of any information, apparatus, product or process disclosed, or represents that its use would not infringe privately-owned rights."

\section{NOTICE}

Reference to a company or product name does not imply approval or recommendation of the product by the University of California or the U.S. Department of Energy to the exclusion of others that may be suitable.

Printed in the United States of America Available from

National Technical Information Service

U.S. Department of Commerce

5285 Port Royal Road

Springfield, VA 22161

Price: Printed Copy $\$$; Microfiche $\$ 3.00$

\begin{tabular}{|c|c|c|c|}
\hline Page Range & $\begin{array}{c}\text { Domestic } \\
\text { Price } \\
\end{array}$ & Page Range & $\begin{array}{c}\text { Domestic } \\
\text { Price }\end{array}$ \\
\hline $001-025$ & S 4.00 & $326-350$ & $\$ 12.00$ \\
\hline $026-050$ & 4.50 & $351-375$ & 12.50 \\
\hline $051-075$ & 5.25 & $376-400$ & 13.00 \\
\hline $076-100$ & 6.00 & $401-425$ & 13.25 \\
\hline $101-125$ & 6.50 & $426-450$ & 14.00 \\
\hline $126-150$ & 7.25 & $451-475$ & 14.50 \\
\hline $151-175$ & 8.00 & $476-500$ & 15.00 \\
\hline $176-200$ & 9.00 & $501-525$ & 15.25 \\
\hline $201-225$ & 9.25 & $526-550$ & 15.50 \\
\hline $226-250$ & 9.50 & $551-575$ & 16.25 \\
\hline $251-275$ & 10.75 & $576-600$ & 16.50 \\
\hline $276-300$ & 11.00 & $601-u p$ & -1 \\
\hline $301-325$ & 11.75 & & \\
\hline
\end{tabular}

II Add $\$ 2.50$ for each additional 100 page increment from 601 pages up. 


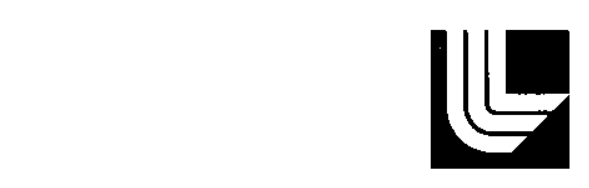

LAWRENCE LIVERMORE LABORATORY

University of Cahtornia Livermore, California 94550

UCRL-52675

\title{
ARTILLERY PEAK ORIENTATION STUDY, MOHAVE COUNTY, ARIZONA
}

\author{
K. P. Puchlik \\ D. L. Leach \\ D. Cazes
}

MS. date: March 12, 1979 



\section{CONTENTS}

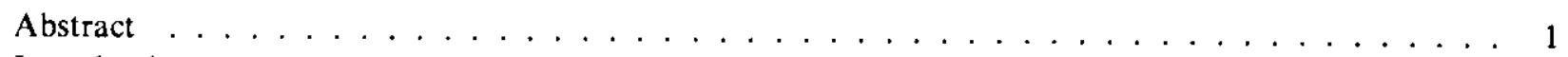

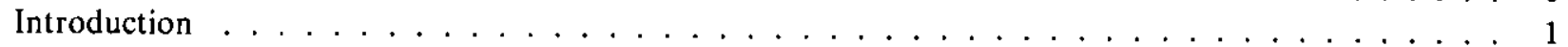

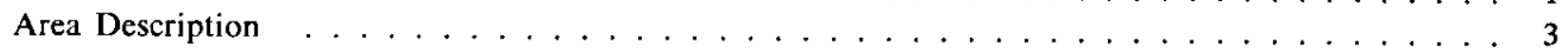

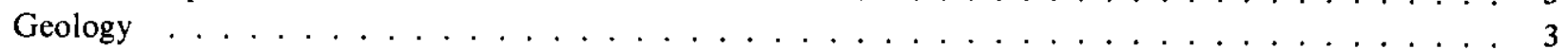

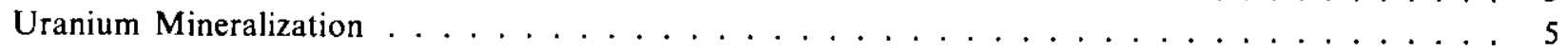

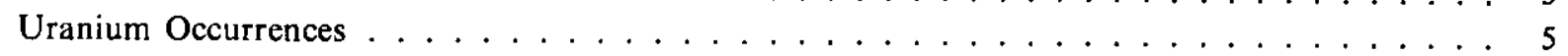

Sample Collection and Field Measurements $\ldots \ldots \ldots \ldots \ldots \ldots$

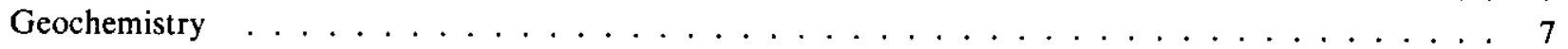

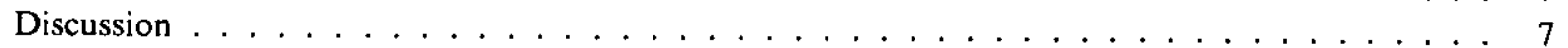

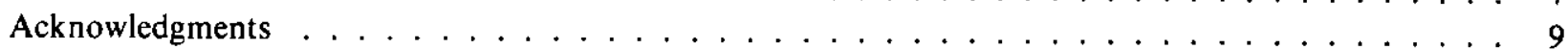

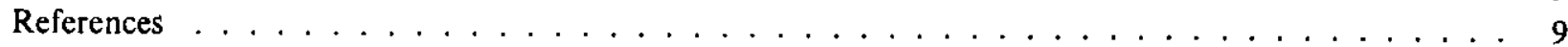

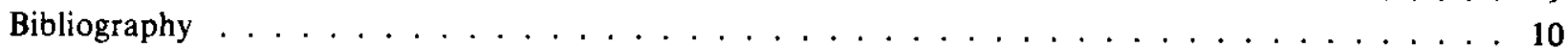

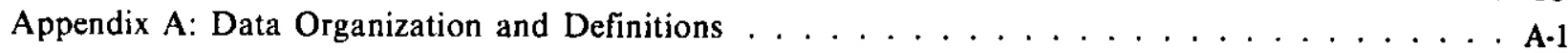

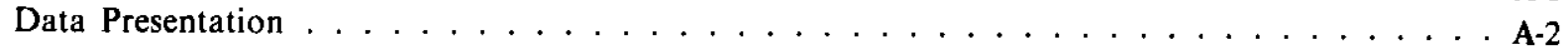

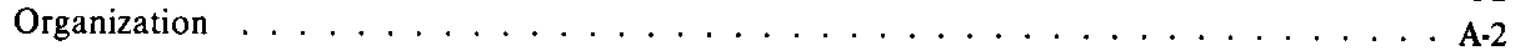

Hardcopy Tables . . . . . . . . . . . . . . . . . A-2

Microfiche Tables . . . . . . . . . . . . . . . . A-2

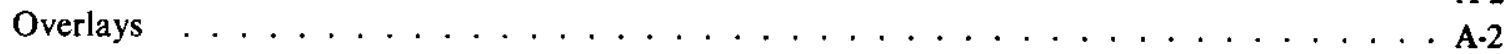

Histograms and Cumulative Frequency Curves $\ldots \ldots \ldots \ldots \ldots$

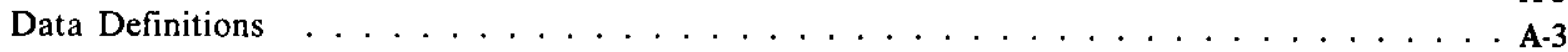

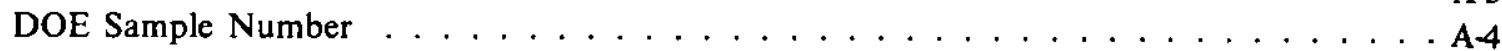

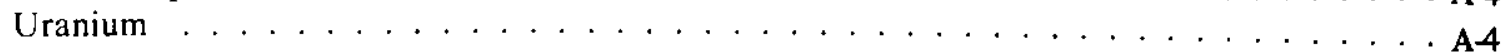

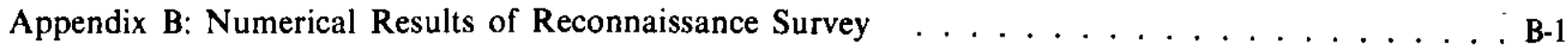

\section{FIGURES}

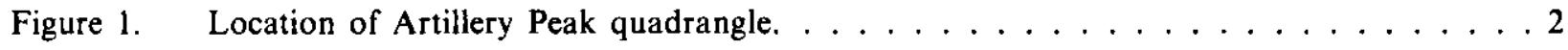

Figure 2. Generalized geologic map for Arizona pilot study I. . . . . . . . . . . 4

Figure 3. Mineral occurrences of the Artillery Peak quadrangle. . . . . . . . . . . 6

Figure A-1. Uranium and thorium concentration in sediment samples. . . . . . . . . A-3

Figure A-2. Histogram (A) and cumulative frequency (B) plots for uranium concentration in sediment samples plotted on Overlay 1 A. . . . . . . . . . . . . . A-5

Figure A-3. Histogram (A) and cumulative frequency (B) plots for thorium concentration in sediment samples plotted on Overlay $1 \mathrm{C} . \ldots \ldots \ldots$. . . . . . . . . . . . . .

\section{TABLES}

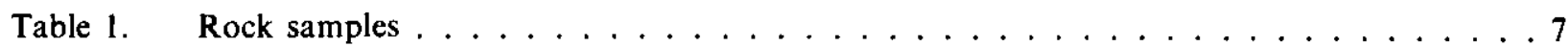

Table B-1. Sediment analysis; dry and stream sites . . . . . . . . . . . . . B-2

\section{MICROFICHE TABLES (rear pocket)}

\section{OVERLAYS}

Overlay 1A. Site Locations, Sediment Samples

Overlay 1B. Total Uranium Concentrations, Sediment Samples

Overlay 1C. Total Thorium Concentrations, Sediment Samples 



\title{
ARTILLERY PEAK QUADRANGLE, ARIZONA, ORIENTATION STUDY
}

\begin{abstract}
We present the results of an orientation study of uranium concentrations in the Artillery Peak quadrangle, Arizona, a part of the Prescott $1^{\circ} \times 2^{\circ}$ quadrangle of the National Topographic Map Series (NTMS). Uranium concentrations, as well as those of 25 other elements, were measured by neutron activation analysis of wet, dry, and rock samples collected throughout the region. Uranium is found in veins and disseminations in the Precambrian rocks and in carbonaceous, tuffaceous lacustrine rocks of the Tertiary Artillery Formation. Data suggest that uranium is associated with resistate mineral phases. Data also show that stream sediments samples may not be an accurate way to determine uranium concentrations in poorly exposed lacustrine deposits similar to those in the Artillery Formation. Analytical data and field measurements are presented in tabular hardcopy and fiche format; full-size overlays are included for use with the Artillery Peak NTMS Quadrangle map and show water sample sites, water-sample uranium locations, sediment sample sites, and sediment-sample total uranium concentrations.
\end{abstract}

\section{INTRODUCTION}

The National Uranium Resource Evaluation (NURE) Program was established to evaluate domestic uranium resources in the continental United States and to identify areas favorable for uranium exploration. The Grand Junction Office (GJO) of the Department of Energy (DOE) is responsible for administering and coordinating NURE program efforts. Lawrence Livermore Laboratory (LLL) is currently reporting on its part of the hydrogeochemical and stream sediment reconnaissance (HSSR) of 1.8 million $\mathrm{km}^{2}$ in 10 western states. Other DOE laboratories have responsibilities for similar reconnaissance in the rest of the continental United States including Alaska. The individual laboratories are responsible for acquiring a proper set of field samples in their areas, processing and analyzing the materials, and compiling the data in report form. The resulting HSSR reports are made available to the public by DOE-GJO through simultaneous release at a number of sites in the U.S. To facilitate the reporting process and make the information available, LLL releases the data as raw data reports with little or no interpretative discussion concerning its significance. The data are reviewed and presented in tabular form with map overlays. Interpretative reports will follow after all the raw data have been released.

The LLL approach to reconnaissance coverage of the 10 western states was to subdivide the area into commonly recognized geologic provinces. These provinces were further subdivided into sample acquisition or project areas, each sampled in a reconnaissance phase with geological contractors monitored by the LLL field quality assurance group. These areas are currently available or are being reported as NTMS sheets open-filed by DOE. Lawrence Livermore Laboratory also carried out one or more "pilot" or orientation studies in the geological province to develop and evaluate sampling and analytical techniques. A series of these studies was conducted in Arizona, where each region was selected to represent different geological environments and uranium mineralization. This study in the Artillery Peak quadrangle (Fig. 1) characterizes an arid area of the Mohave subprovince of the Basin and Range province that contains known uranium occurrences. The object of the study was to determine if dry stream sediment analysis could detect uranium in siltstones and sandstones of the Artillery Formation. The area was chosen because it is typical of the Cenozoic fluvial and 


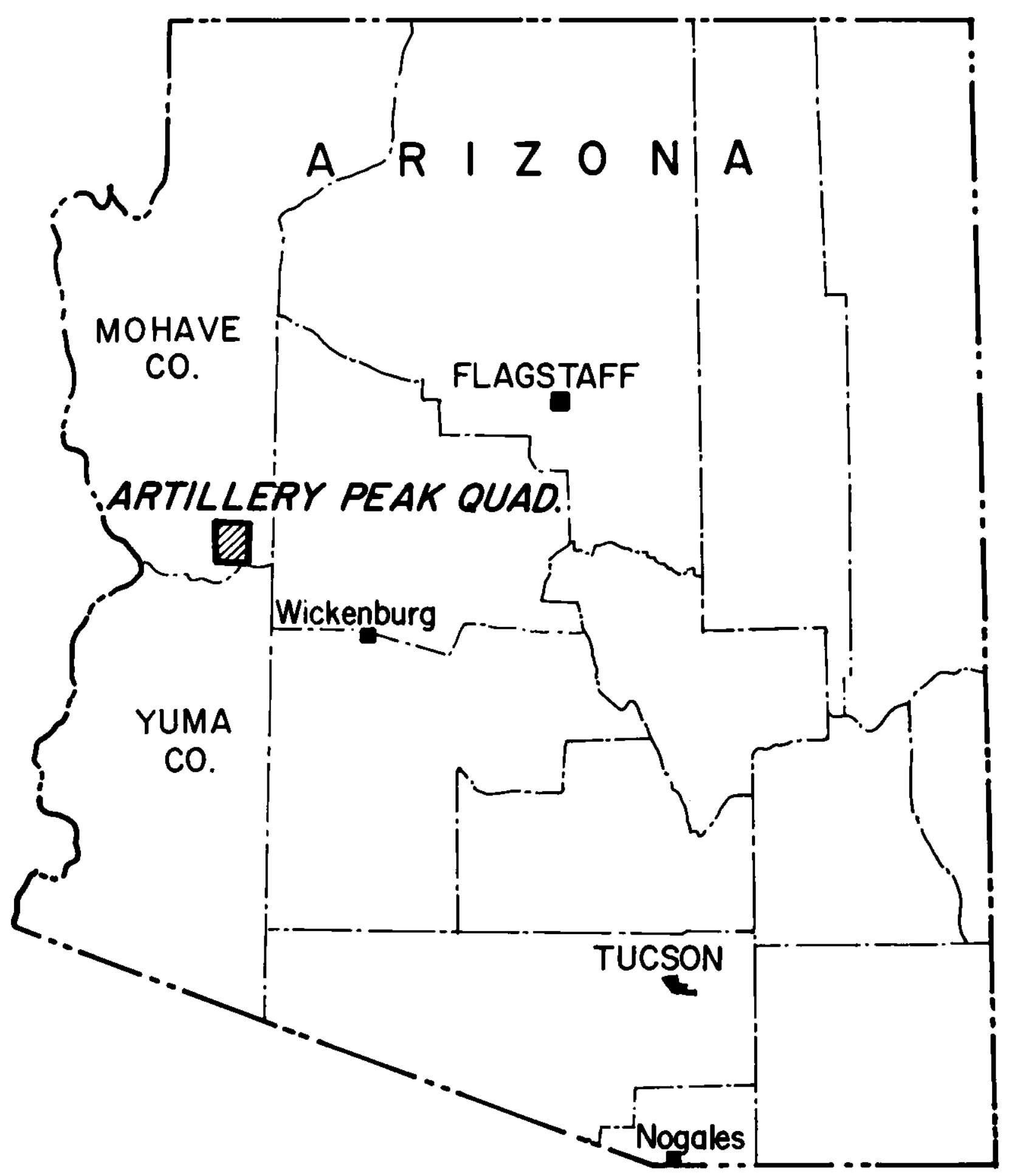

INDEX MAP OF

ARTILLERY PEAK PILOT STUDY AREA

FIG. 1. Location of Artillery Peak quadrangle. 
lacustrine deposits that have been the target of much industry exploration in southwest Arizona. Information obtained here could be applied to a regional reconnaissance for uranium in a similar Cenozoic environment in the southwestern United States.

\section{AREA DESCRIPTION}

The Artillery Peak quadrangle is located on the border between Mohave and Yuba Counties in west-central Arizona (Fig. 1). The sampled area covers approximately $653 \mathrm{~km}^{2}\left(250 \mathrm{mi}^{2}\right)$ and has topographic features characteristic of the Mohave block of the southern Basin and Range province. The area is bordered by the Bill Williams and Big Sandy Rivers on the east and southeast and by the Rawhide Mountains on the southwest. To the north, it opens up into an unnamed desert plain. A major part of the quadrangle is occupied by the Artillery Mountains, which consist of low, deeply dissected hills cut by drainages that slope toward the Bill Williams and Big Sandy Rivers. The central portion of the area also has relatively flat-topped, basaltcapped hills called Black Mesa and Plancha Mountain.

\section{GEOLOGY}

The generalized geology for the Artillery Peak quadrangle is shown in Fig. 2. The rocks range in age from Precambrian(?) to recent. Lasky and Webber ${ }^{1}$ first mapped and described the Tertiary rocks of the quadrangle, and, more recently, Shackelford, ${ }^{2}$ Lucchitta, ${ }^{3}$ and Otten ${ }^{4}$ have studied the area. Correlation of their work suggests that the ages of the Tertiary units at Artillery Peak are slightly different from those assigned by Lasky and Webber. ${ }^{1}$ Thus, based on the most recent work, the rocks consist of:

- A basement complex composed mainly of probable Precambrian granite, gneiss, and schists and minor amounts of Paleozoic metamorphosed limestone, shale, and quartzite.

- The Eocene(?) Artillery Formation, consisting of basin deposits of clay, conglomerate, arkose, sandstone, shale (and some limestone), tuff, and basalt.

- Miocene(?) tuffs and fluvial rocks.

- The partile manganiferous Miocene(?) Chapin Wash Formation consisting of alluvial fans and playa deposits.

- Andesite bodies intruding the base of the Chapin Wash Formation.

- The mid-Miocene(?) Cobweb Basalt.

- The Pliocene(?) Sandtrap Conglomerate containing a local basalt member.

- Pleistocene(?) basalt flows that cap some of the prominent mesas.

- Late Pleistocene alluvium.

- Recent alluvium and rock slide material.

Angular unconformities underlie nearly all units, and multiple stages of deformation have been recognized. One visible feature is the displacement of the Precambrian and Paleozoic rocks onto the Artillery Formation, which was first described as a thrust fault by Lasky and Webber. ${ }^{1}$ In some cases, formations and ranges listed above have probably been redistributed by this structural event. The movement occurred before Miocene volcanic extrusion, and there is a possibility that the Artillery Formation was partly derived from the advancing front of the allochthonous plate. This would date the event at lower-Eocene to Oligocene.

Post-Miocene normal faulting could have established the general position of the depression between the Artillery and Rawhide Mountains. A northwest-trending, closed gravel basin formed in which the Chapin Wash Formation and the Cobweb Basalt were deposited. The Sandtrap Conglomerate was deposited after the basin was established. Lasky and Webber ${ }^{1}$ refer to this down-dropped block as the Manganese Basin. The Chapin Wash Formation, the Cobweb Basalt, and the Sandtrap Conglomerate are referred to by Lasky and Webber ${ }^{1}$ as the formations of the Manganese Basin. 


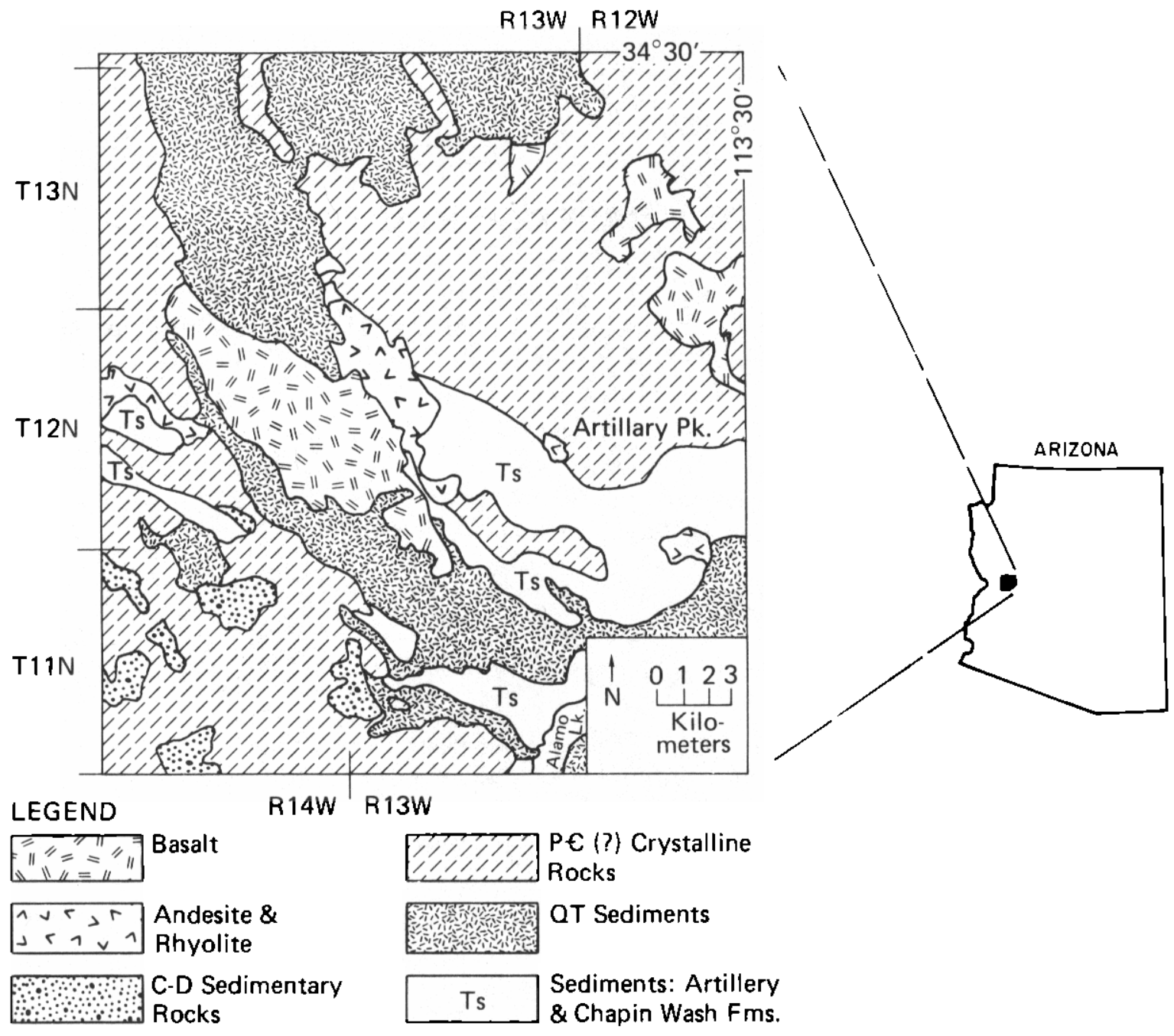

FIG. 2. Generalized geologic map for Arizona pilot study I.

The Manganese Basin formations are folded into a shallow northwesterly syncline paralleling the basin trend. Numerous minor northwest-trending folds modify the syncline, and this folding has produced some movement at the base of the Sandtrap Conglomerate. Some sympathetic folding in the Precambrian rocks may have taken place at this time. Recently, Rehrig and Reynolds ${ }^{5}$ suggested that the foliation of the Precambrian basement is due to large-scale Tertiary metamorphism. The thrust (or gravity slide) fault is also folded. Davis $e t$ al. ${ }^{6}$ have suggested that some movement during this time resulted from regional low-angle faulting.

The folded rocks along both sides of the Manganese Basin are broken by north-westerly normal faults. Some faults in the Rawhide Mountains appear to follow veins of pre-Artillery age, indicating that the zones of weakness may have developed earlier (possibly during a larger and ill-defined Mesozoic metamorphism). The faults along Artillery Mountain on the northeast side of the basin are regionally extensive and involve Pliocene(?) basalts as well as older rocks. The sharply defined faults appear to control the present topography and movement appears to have been recurrent throughout most of the basin's history. 


\section{URANIUM MINERALIZATION}

The main mineralized area of west-central Arizona is the Anderson Mine, which lies just east of the Artillery Peak quadrangle. The Anderson host rocks are Tertiary lake-bed deposits more than $60 \mathrm{~m}$ thick. The fossiliferous unit is faulted and folded and locally silicified containing lensing lignetic units. The principal uranium mineral is carnotite of an unknown source. This area is described in detail by Reyner et al. ${ }^{7}$ and Otten. $^{4}$

The isolated exposures of the Anderson units make regional stratigraphic correlation difficult. However, Reyner et al. ${ }^{7}$ has tentatively correlated the lake-bed host rocks with the Chapin Wash Formation. We should note that, in the Artillery Peak quadrangle, the older Artillery Formation contains the known uranium occurrences, whereas the younger Chapin Wash Formation does not. These formations, as well as the Anderson Mine host rocks, potentially underlie much of the Artillery Peak area. Many claims have been staked and drilling done in the scattered uranium occurrences.

This erratic mineralization and the possible existence of multiple, buried uranium-bearing units presents an excellent opportunity to study how geochemical techniques apply to defining a uranium district. Uranium is known to occur in western Arizona in many locations within variable sedimentary host rocks. Thus, the information learned in the Artillery Peak quadrangle could help define similar districts in fluvial and lacustrine Cenozoic deposits within the Basin and Range province of the southwest.

\section{URANIUM OCCURRENCES}

The uranium occurrences are described by $\mathrm{Keith}^{8}$; they are shown on Fig. 3 along with the locations of other known minerals. The main uranium occurrences in the quadrangle are in two drainages immediately west of Artillery Peak containing the Masterson and Lucky Four uranium claim groups. This area has excellent exposures of the Artillery Peak lacustrine units, and the uranium occurrences have not been overly disturbed by exploration and mining operations. Anomalous areas were defined by scintillometer, but no uranium minerals were observed on the surface. Industry drilling however, has reported uranium minerals at shallow depths.

Uranium occurs mainly in carbonaceous, tuffaceous, lacustrine siltstones, and sandstones near the base of the Artillery Formation. The uranium-bearing unit is overlain by limestone and overlies an arkosic sandstone. The sandstone in turn, overlies a Precambrian basement of schists, gneisses, and granite. Although the area is staked, no work beyond the drilling and trenching stage has been done.

Bedded uranium is also found in the Artillery Formation in Ester Basin at the northern end of the Rawhide Mountains, where the geological setting is similar to the Masterson area. Quite a bit of drilling and trenching is evident.

To the west near Rawhide Wash, Artillery Formation uranium (the Red Hills prospect) is underlain by schist and gneiss. Here, the small outcroping of the Artillery Formation consists of a breccia containing fragments of schist, felsite material, conglomerate, and limestone cemented with silica, carbonates, and manganese oxide. This breccia may be either tectonic or sedimentary. Prospect pits were sunk in radioactive shear zones. The breccia in the shear zone is cemented with barite, fluorite, and secondary copper minerals.

On the northwest side of the sheet, the White Owl and Gray Boy claims consist of prospects, pits, and discovery trenches. Radioactivity is associated with pegmatite dikes and fault zones in a Precambrian granite. The fault zone contains fluorite, chalcedonic quartz, and calcite. There is also some Artillery Formation(?) in place.

Other areas of interest include the radioactive schists and veins in the Precambrian granite of the northeastern part of the sheet (State Mine) and in the Fools Peak area of the Rawhide Mountains. These latter occurrences were not studied in any detail. 


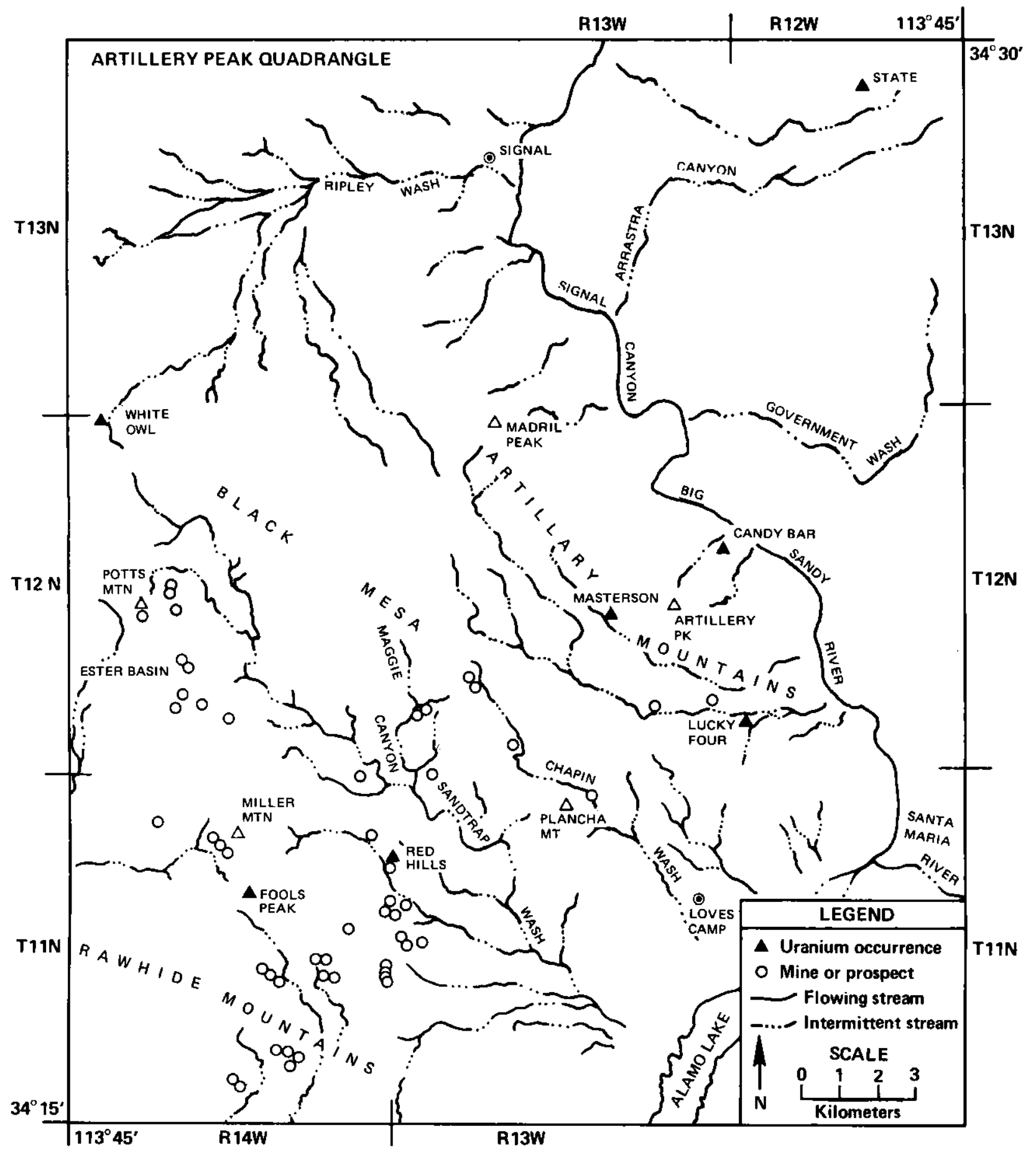

FIG. 3. Mineral occurrences of the Artillery Peak quadrangle. 


\section{SAMPLE COLLECTION AND FIELD MEASUREMENTS}

Sampling took place during June 1977 and required six man-weeks of work. The area was sampled over a short time to reduce the effect of temporal variations. The media collected include dry and wet stream sediments and a complete suite of rock types.

The proper selection of the sample site is the most important technical aspect of sample acquisition. Sites were selected so that the samples would represent the sample-acquisition areas and minimize contamination by environmental pollution (ranches, bridges, mines, etc.). However, samples were taken every $400 \mathrm{~m}$ both up and downstream from the Masterson, Lucky Four, Red Hills, and Ester Basin uranium occurrences to study the geochemical mobility of uranium.

Sediments at each site were collected as a composite of five subsamples taken $5 \mathrm{~m}$ apart. Aluminum or plastic shovels were used and collapsed bank and wind-deposited materials were avoided. Dry samples were field-sieved (stainless steel sieve) to remove fragments larger than 1/4 in. At active stream sites, the composite sample was taken from the stream bottom; approximately $2 \mathrm{~kg}$ of the dry or damp material was sealed in double polyethylene bags for return to the laboratory. In the receiving laboratory, the sediments were dried at $110^{\circ} \mathrm{C}$ and sieved. The portion less than $1000 \mu \mathrm{m}$ but greater than a $500 \mu \mathrm{m}$ was collected. Selected samples were also sieved to several other size fractions, followed by partial extraction of uranium by aceticacid-hydrogen-peroxide leach. Mineralogy for those samples was determined by optical methods.

Relatively unweathered rock samples, judged to be characteristic of the locale, were collected at some of the sediment-sampling sites. In addition, mineralized samples were taken at some uranium occurrences. The rocks were examined optically and are described in Table 1.

At each sample site, a field-data form was completed. The form contains check spaces for site characteristics.

\section{GEOCHEMISTRY}

A logarithmic histogram and a cumulative-frequency curve for uranium and thorium are provided for the sediment samples. The median concentrations are $3.1 \mathrm{ppm}$ for uranium and $15.2 \mathrm{ppm}$ for thorium. Representing and interpreting data sets where individual samples must be compared with different threshold values is a problem in a drainage survey covering a range of rock types. Gouett et al. ${ }^{9}$ has shown that log transformations on raw geochemical survey data cause enhancement of the background populations and suppression of the anomalous population in the overall statistical distribution. For example, sediment samples with $5 \mathrm{ppm}$ uranium may represent an anomalous value in a carbonate terraine but, at the same time, constitute background values in or near outcrops of rhyolitic rocks and silicic intrusives. Therefore, population recognition and sorting is vital to the statistical interpretation. Thus, this report is not a detailed interpretation of the data.

\section{DISCUSSION}

Uranium concentrations in stream sediments from the Artillery Formation outcrop area have a median value of 3.5 vs $2.8 \mathrm{ppm}$ for sediments from other rock types in the quadrangle. Thorium median concentrations are 16 and $14.9 \mathrm{ppm}$, respectively. The uranium distribution is erratic in the Artillery Peak outcrop drainages, and the Masterson and Lucky Four uranium occurrences were not indicated either by the total uranium concentration or the measurements of partially extractable uranium, which were obtained by a hydrogen-peroxide-acetic-acid leach method described by Rose $e t$ al. ${ }^{10}$

The highest uranium concentrations in stream sediments from the Artillery Formation outcrop area are in the 60- to $250-\mu \mathrm{m}$ fraction. The rare earths and thorium also show elevated concentrations. Partially extractable uranium is consistently low (less than 5 to $10 \%$ ) in all size fractions, indicating that little adsorbed uranium is present. 
TABLE 1. Rock Samples.

Sample No. Description

$9848 \quad$ Mixed sandy conglomerate:

Red; slightly friable; matrix supported; fragments range from granules to pebbles; abundant K-feldspar clasts, biotite, and quartz fragments; rounded lithic pebbles; disseminated mica flakes; calcareous veinlets; very fine sand matrix; hematite-stained calcareous cement.

Heterogeneous granular sandstone:

Red; friable, poorly sorted, framework supported; contains subrounded quartz, subangular lithic fragments, mica, minor feldspar, and magnetite; rare pebble-size fragments; matrix ranges from very fine sand to silt.

9861 Basalt:

Grey; rare, round-quartz amygdules; anhedral olivine, minor hematite grains; anhedral quartz in grey aphanitic groundmass.

9876 Altered basaltic andesite porphyry:

Grey; slightly vesicular, cryptocrystalline groundmass; calcite-filled vesicles, weathered-out amphibole, lath-shaped plagioclase $<2 \mathrm{~mm}$; some vesicles filled with white friable material, possibly zeolite; iddingstie occurs as disseminated brown vitreous specks; hackly fracture.

Basaltic andesite:

Dary grey, aphanitic, glassy, highly weathered; friable; weathered-out quartz amygdules; euhedral plagioclase laths less than $1 \mathrm{~mm}$, anhedral K-feldspar, magnetite, rare quartz vugs; siliceous detrital coating contains abundant quartz, feldspar, hematite and magnetite grains.

Granite pegmatite:

Coarse-grained phaneritic; pink perthitic euhedral K-feldspar; euhedral to anhedral biotite tablets altering to chlorite, anhedral quartz.

9889 Quartz vein material:

Milky; perthitoid; aphanitic; Mn oxide and altered chlorite material on weathered surface; grades into chert; hackly fracture.

9910 Mixed calcareous pebble-granule conglomerate:

Light grey; friable; contains quartzite, andesite, feldspar and mixed lithic fragments; fragments are mostly subangular and range from 1 to $25 \mathrm{~mm}$. Calcite vugs; fine-grained matrix with calcareous cement.

9912 Sandy conglomerate:

Red; poorly sorted; thinly laminated; contains heterogeneous subangular lithic granules including andesite, quartzite, and feldspar; hematite-stained matrix ranges from silt to fine-sand size.

$9950 \quad$ Quartz monzonite:

Coarse-grained hypidiomorphic; euhedral perthitic K-feldspar, lath-shaped plagioclase, minor interlocking anhedral quartz, anhedral-to-subhedral biotite; weathers light brown.

10095 Basalt porphyry:

Dark grey; rare anhedral feldspar; aphanitic groundness; red and black Fe oxide on weathered surface; white calcareous deposit on some surfaces; hackly fracture. 
These results suggest that uranium concentration in stream sediments from drainages in the Artillery Formation is dominated by uranium in resistate mineral phases, which are derived possibly from the basal arkosic unit in the Artillery Formation or from Precambrian rocks. In addition the low concentrations of total and acid-extractable uranium in stream sediments near the uranium occurrences may be due to low levels of mobile uranium at the prospect outcrops. The exposed fluvial and lacustrine units may have been leached of more mobile uranium by the action of rainwater. These results suggest that stream sediment samples may not be an effective exploration method for poorly exposed fluvial and lacustrine deposits similar to those in the Artillery Formation.

\section{ACKNOWLEDGMENTS}

The authors would like to thank the following people who helped to make this report possible: The LLL General Chemistry Division performed the special chemistry analyses of the water samples. The LLL Nuclear Chemistry Division, under the direction of C. Smith, performed the neutron activation analyses of the sediment, rocks, and water samples. The LLL Computations Division was responsible for data management and storage. Special thanks go to $\mathbf{S}$. Grotch for statistical advice and generation of the correlation data. Geochemist D. Leach, now with the U.S. Geological Survey, designed the sampling methodology and helped on interpretation. The senior author fielded the sampling program and was assisted by D. Cazes, M. Knowlton, R. Blocker and L. Marsh.

\section{REFERENCES}

1. S. G. Lasky and B. N. Webber, Manganese Deposits in the Artillery Mountains Region, Mohave County, Arizona, U.S. Geol. Survey Bull. 936-R, Pl. 62, scale 1:31,680 (1944).

2. T. J. Shackelford, Structural Geology of the Rawhide Mountains, Mohave Co., Arizona, Ph.D. Thesis, University of Southern California (1976).

3. I. Lucchitta, "Early History of the Colorado River in the Basin and Range Province," Geol. Soc. America Bull. 83, 1933 (1972).

4. J. K. Otten, Geology of Uraniferous Tertiary Rocks in the Artillery Peak-Date Creek Basin, WestCentral Arizona, U.S. Geological Survey, Reston, Va., Circular 753, p. 35 (1977).

5. W. A. Rehig and S. J. Reynolds, "A Northeast Zone of Metamorphic Core Complexes in Arizona," Geol. Soc. America Abstracts (Geological Society of America Annual Meeting, Spokane, Wash., 1977).

6. G. A. Davis, K. V. Evans, E. G. Frost, S. H. Lingery, and T. J. Schackelford, "Enigmatic Miocene LowAngle Faulting, Southeastern California and West-Central Arizona-Suprastructural Tectonics?," Geol. Soc. America Abstracts (Geological Society of America Annual Meeting, Spokane, Wash., 1977).

7. M. L. Reyner, W. R. Ashwill, and R. L. Robinson, Geology of Uranium Deposits in Tertiary Lake Sediments of Southwestern Yavapai Co., Arizona, U.S. Atomic Energy Commission, Washington, D.C., RME 2057 (1956).

8. S. B. Keith, "Uranium," In Coal, Oil, Natural Gas, Helium, and Uranium in Arizona, Arizona Bureau of Mines, Bulletin 182 (1970).

9. G. S. Gouett, W. Goodfellow, R. Chapman, and C. Crork, "Exploration Geochemistry-Distribution and Recognition of Anomolies," Math. Geol. 7, 5 (1975).

10. A. W. Rose, L. K. Mackenzie, and H. H. Suhn, Geochemical Drainage Surveys for Uranium: Sampling and Analytical Methods on Trail Surveys in Penn., U.S. Department of Energy, Grand Junction, Col., GJBX 28-76 (1976). 


\section{BIBLIOGRAPHY}

Anderson, C. A., "Older Precambrian Structure in Arizona,"Geol. Soc. America Bull., 62, 1331-1346 (1951).

Arizona Bureau of Mines, the University of Arizona, Tucson, Arizona.

Map of outcrops of Precambrian rocks in Arizona (1962).

Map of outcrops of Paleozoic and Mesozoic rocks in Arizona (1962).

Map of outcrops of Tertiary and Quaternary Igneous rocks in Arizona (1962).

Butler, A. P. and V. P. Byres, "Uranium," Mineral and Water Resources of Arizona, Arizona Bureau of Mines, Bull. 180 282-291 (1969).

Davidson, E. S.,"Water-Resources Appraisal of the Big Sandy Area, Mohave County, Arizona," Arizona Water Bulletin. 6, Pl.1, 1:63,360 (1973).

Davis, Joseph R., and Meir, Allen L., Lithium Reconnaissance of Arizona, U.S. Department of the Interior Geological Survey, Open-file Report No. 76-676 (1976).

Fischer, R. P., "Exploration Guides to New Uranium Districts and Belts." Econ. Geol., 69, 362-376 (1974). Granger, H. C. and R. B. Raup, Reconnaissance Study of Uranium Deposits in Arizona, Geol. Sur. Bull. 1147-A (1962).

Hart, O. M. and D. L. Hetland, Preliminary report on uranium-bearing deposits in Mohave Co., Arizona. U.S. AEC Report RME-4026, Mineralogy/Metallurgy and Ceramics; No. 5540. (June 1953).

Hart, O. M., Uranium Investigations in Mohave Co., Arizona. U.S. AEC report RME-2029, Mineralogy, Metallurgy and Ceramics; No. 6354 (Feb. 1955).

Heindal, L. A. and J. F. Lance, "Topographic, Physiographic, and Structural Subdivisions of Arizona," Arizona Geol. Digest, 3 12-18 (1960).

Keith, S. B., 1970, "Uranium" in Coal, Oil, Natural Gas, Helium, and Uranium in Arizona, Arizona Bureau of Mines, Bulletin 182, 101-146.

McCrory, F. J. and R. T. O'Haire, Map of Known Metallic Mineral Occurrences of Arizona, Arizona Bureau Mines (1961).

McKee, E. D., Sedimentary Basins of Arizona and Adjoining Areas, Geol. Soc. America Bull. 62, 481-506 (1951).

Pierce, H. W., and J. C. Wilt, “ Oil, Natural Gas, and Helium” in Coal, Oil, Natural Gas, Helium and Uranium in Arizona, Arizona Bureau Mines, Bulletin 182, 43-98 (1970).

Preliminary Reconnaissance for Uranium in Mohave County, Arizona; 1952-1956, Atomic Energy Commission and U. S. Geological Survey, Division of Raw Materials, USAEC, Washington, D.C., RME-158.

KJM:nt 


\section{APPENDIX A \\ DATA ORGANIZATION AND DEFINITIONS}




\title{
DATA PRESENTATION
}

\section{ORGANIZATION}

The numerical results of this reconnaissance survey are presented in hardcopy tables (Appendix B), in microfiche tables (back-cover pocket), and in vellum overlays (back-cover pocket). In addition, frequency histograms and cumulative frequency plots of the uranium and thorium concentrations are included in the back of this appendix.

\section{HARDCOPY TABLES}

Selected results of this study are presented in the table in Appendix B. Additional data on the trace elements for each of the samples are reported in the microfiche table. The titles and data reported in the table are given below.

\author{
Sediment analyses; dry and stream sites given in Table B-1. \\ LLL sample number \\ DOE sample number \\ Sample date \\ Sample source and condition \\ Sieve fraction size, upper limit \\ Sieve fraction size, lower limit \\ Possible contamination \\ Quality-control, cross-reference number \\ Uranium concentration, ppm \\ Thorium concentration, ppm
}

\section{MICROFICHE TABLES}

The additional element data gathered for each sample are presented in tables on microfiche film. These tables contain data from neutron activation analyses. The table titles are exactly as in the hardcopy tables, and the columnar entries of the hardcopy tables are repeated as the first part of each microfiche table. This is followed by the element values arranged in alphabetical order according to the element's proper name. Because of the amount of data, the tables are subdivided into several parts presented on separate pages.

\section{OVERLAYS}

Full-size vellum overlays for use with the Artillery Peak 1;62,500 scale, $15^{\prime}$ quadrangle are located in the rear pocket of this report. These may be used with the commercially available USGS map for visual display of the sampling site locations and uranium concentration relative to local geographic features. The map name is given on the overlay. The site symbol is plotted over the geographic location with the site number plotted beside it. The corresponding concentration-range value is indicated in a separate overlay by a symbol whose shape and size varies with the range value. The symbol set employed here is a slightly modified version of that employed by the Geological Survey of Canada in their hydrogeochemical surveys. The range assignments are shown in Fig. A-1. 

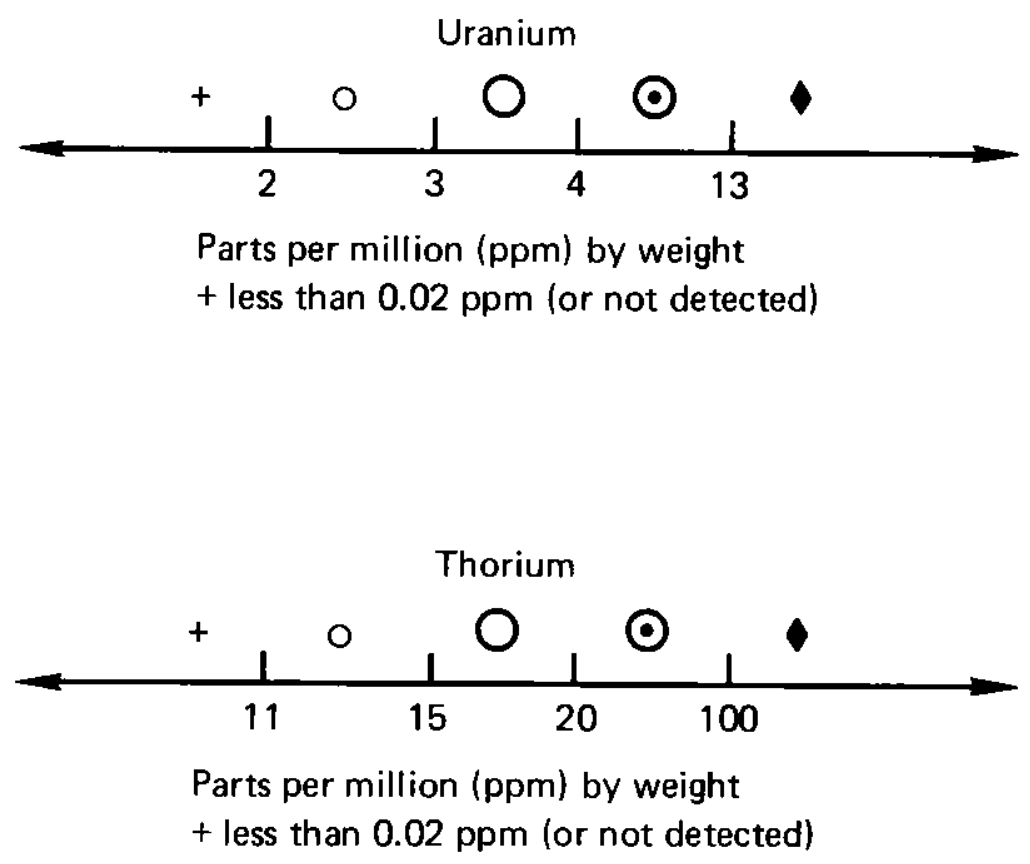

FIG. A-1. Uranium and thorium concentration in sediment samples.

\section{HISTOGRAMS AND CUMULATIVE FREQUENCY CURVES}

Histograms and cumulative frequency plots for uranium concentration on Overlay $1 \mathrm{~A}$ are shown in Fig. A-2 (sediment samples). The histogram and cumulative frequency plot of the thorium values for sediment samples on Overlay 1C are shown in Fig. A-3. These are presented as the logarithm of the elemental concentrations.

\section{DATA DEFINITIONS}

This section presents a brief explanation of the columnar entries for the hardcopy and microfiche data tables.

Blanks in the data tables indicate no measurement available. Detection units for INAA determinations are given in the text. Emission spectrometry detection units are indicated in the data tables by the symbol $(<)$. 


\section{DOE SAMPLE NUMBER}

Each analyzed field sample is assigned a DOE number consisting of 28 characters. Five characters (dashes) are used to delineate the number of subdivisions. The subdivision assignments are:

\begin{tabular}{|c|c|}
\hline Number & Description \\
\hline 01 & Spring water sample untreated. \\
\hline 02 & River or stream water sample untreated. \\
\hline 03 & Well water sample untreated. \\
\hline 04 & Lake or reservoir water sample untreated. \\
\hline 06 & $\begin{array}{l}\text { Spring water sample filtered through a } 0.45-\mu \mathrm{m} \text { membrane filter and acidified to a } \mathrm{pH} \text { of } \\
\leq 1 \text { with high purity nitric acid }\left(\mathrm{HNO}_{3}\right) \text {. }\end{array}$ \\
\hline 07 & $\begin{array}{l}\text { River or stream water sample filtered through a } 0.45-\mu \mathrm{m} \text { membrane filter and acidified to } \\
\text { a } \mathrm{pH} \text { of } \leq 1 \text { with high purity nitric acid }\left(\mathrm{HNO}_{3}\right) \text {. }\end{array}$ \\
\hline 08 & $\begin{array}{l}\text { Well water sample filtered through a } 0.45-\mu \mathrm{m} \text { membrane filter and acidified to a } \mathrm{pH} \text { of } \\
\leq 1 \text { with high purity nitric acid }\left(\mathrm{HNO}_{3}\right) \text {. }\end{array}$ \\
\hline 09 & $\begin{array}{l}\text { Lake or reservoir water sample filtered through a } 0.45-\mu \mathrm{m} \text { membrane filter and acidified } \\
\text { to a } \mathrm{pH} \text { of } \leq 1 \text { with high purity nitric acid }\left(\mathrm{HNO}_{3}\right) \text {. }\end{array}$ \\
\hline 21 & Spring water sample filtered through a $0.45-\mu \mathrm{m}$ membrane filter. \\
\hline 22 & River or stream water sample filtered through a $0.45-\mu \mathrm{m}$ membrane filter. \\
\hline 23 & Well water sample filtered through a $0.45-\mu \mathrm{m}$ membrane filter. \\
\hline 24 & Lake or reservoir water sample filtered through a $0.45-\mu \mathrm{m}$ membrane filter. \\
\hline 70 & Wet sediment sample dried at $110^{\circ} \mathrm{C}$ and sieved to the reported particle size range. \\
\hline 71 & $\begin{array}{l}\text { Lake or reservoir sediment sample dried at } 110^{\circ} \mathrm{C} \text { and sieved to the reported particle size } \\
\text { range. }\end{array}$ \\
\hline 72 & Dry sediment sample dried at $110^{\circ} \mathrm{C}$ and sieved to the reported particle size range. \\
\hline 73 & $\begin{array}{l}\text { Playa sediment sample taken by hand auger over the reported depth, dried at } 100^{\circ} \mathrm{C} \text {, } \\
\text { and crushed to a fine powder. }\end{array}$ \\
\hline 74 & Rock sample crushed and sieved to less than 2 \\
\hline
\end{tabular}

Position $1-2$ 4-10 $12-19$ 21 23-24 $26-28$
ST,

LAT, LONG, $\mathrm{L}$, TY, RPL,
Description

State, the two-digit Federal Information Processing Standard (FIPS) designated for the state corresponding to the sample site location $(\mathrm{AZ}=04, \mathrm{CA}=06, \mathrm{ID}=16, \mathrm{NV}=32$, $\mathrm{OR}=41, \mathrm{UT}=49, \mathrm{WA}=53$ ).

Latitude of site in decimal degrees.

Longitude of site in decimal degrees.

Originating laboratory $(1=\mathrm{LLL})$

DOE Sample Type. A two-digit code describing the sample source, medium, and overall geochemical treatment (field and laboratory) prior to analysis. See DOE Sample Type Numbers below for specific assignments.

Replication Code. Three-digits used to distinguish between samples from the same site. The first indicates sample type $(1=$ sediment, 2 = water $)$, the second identifies the field duplicate, and the third identifies analytical splits.

\section{URANIUM}

The trace-element concentration of uranium in the sample as determined by DNC is given in parts per billion (ppb) by weight for waters and in parts per million (ppm) by weight for sediments. Where DNC values are not available, INAA determinations have been substituted and flagged with an asterisk (*). The error column contains a statistical estimate of measurement uncertainty expressed as a percentage of the concentration. 

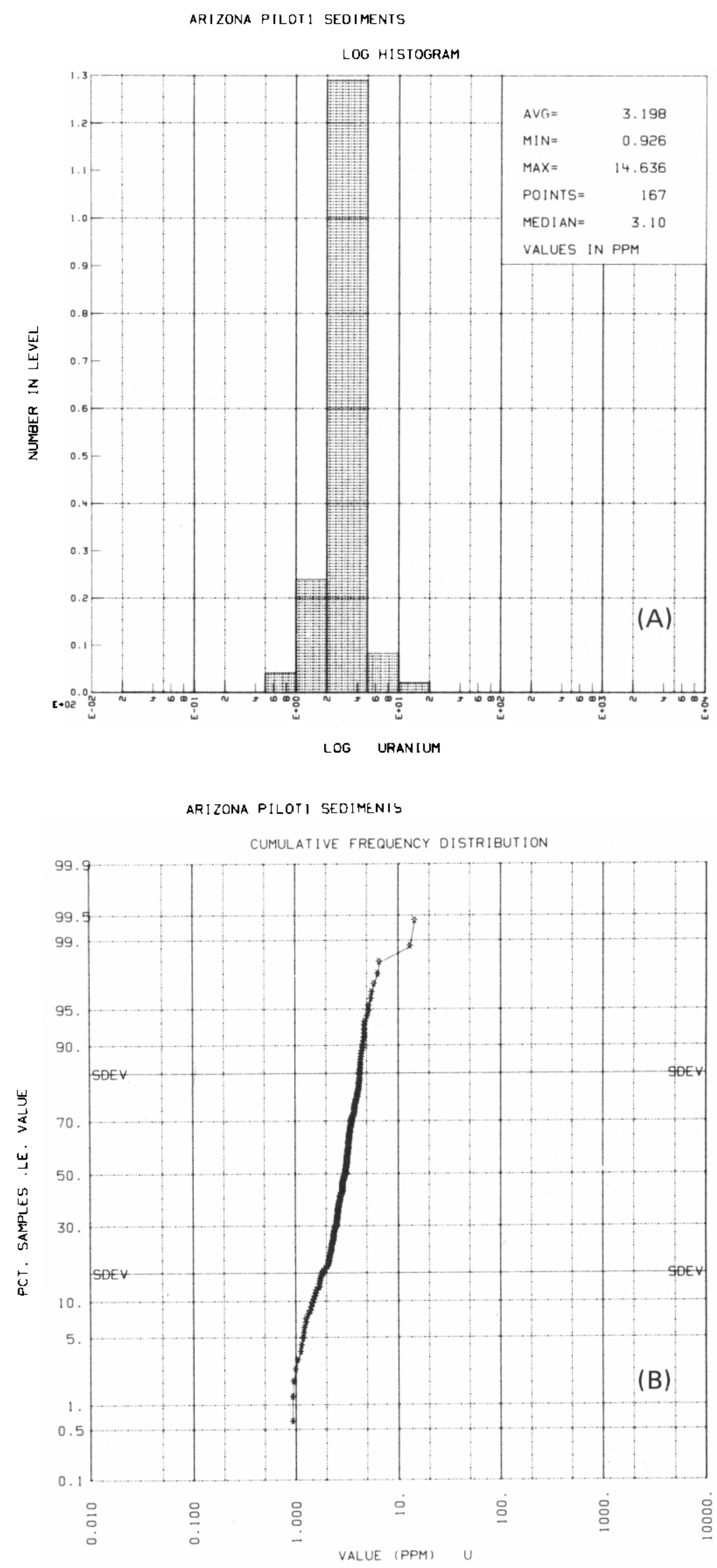

FIG. A-2. Histogram (A) and cumulative frequency (B) plots for uranium concentration in sediment samples plotted on Overlay $1 \mathrm{~A}$. 

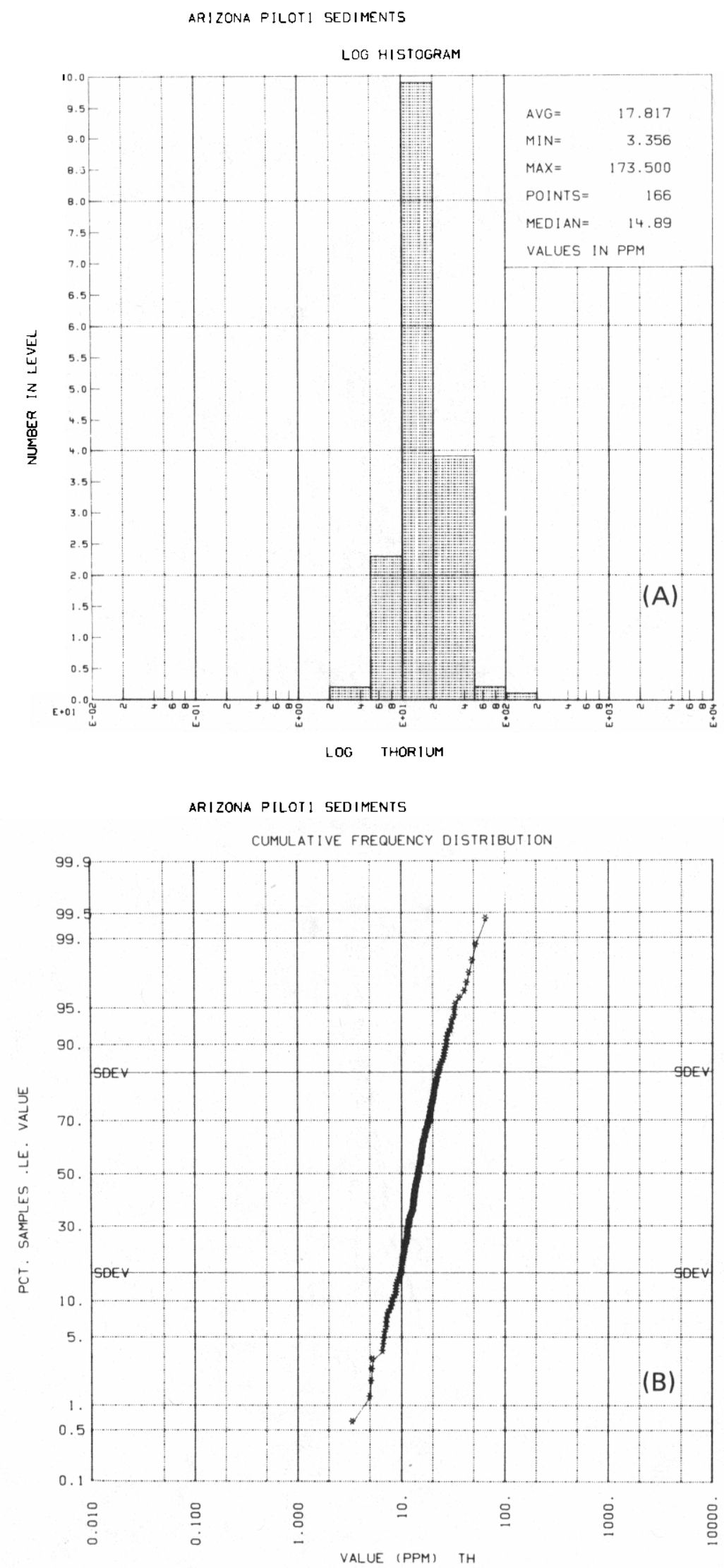

FIG. A-3. Histogram (A) and cumulative frequency (B) plots for thorium concentration in sediment samples plotted on Overlay 1C. 
NUMERICAL RESULTS OF RECONNAISSANCE SURVEY 


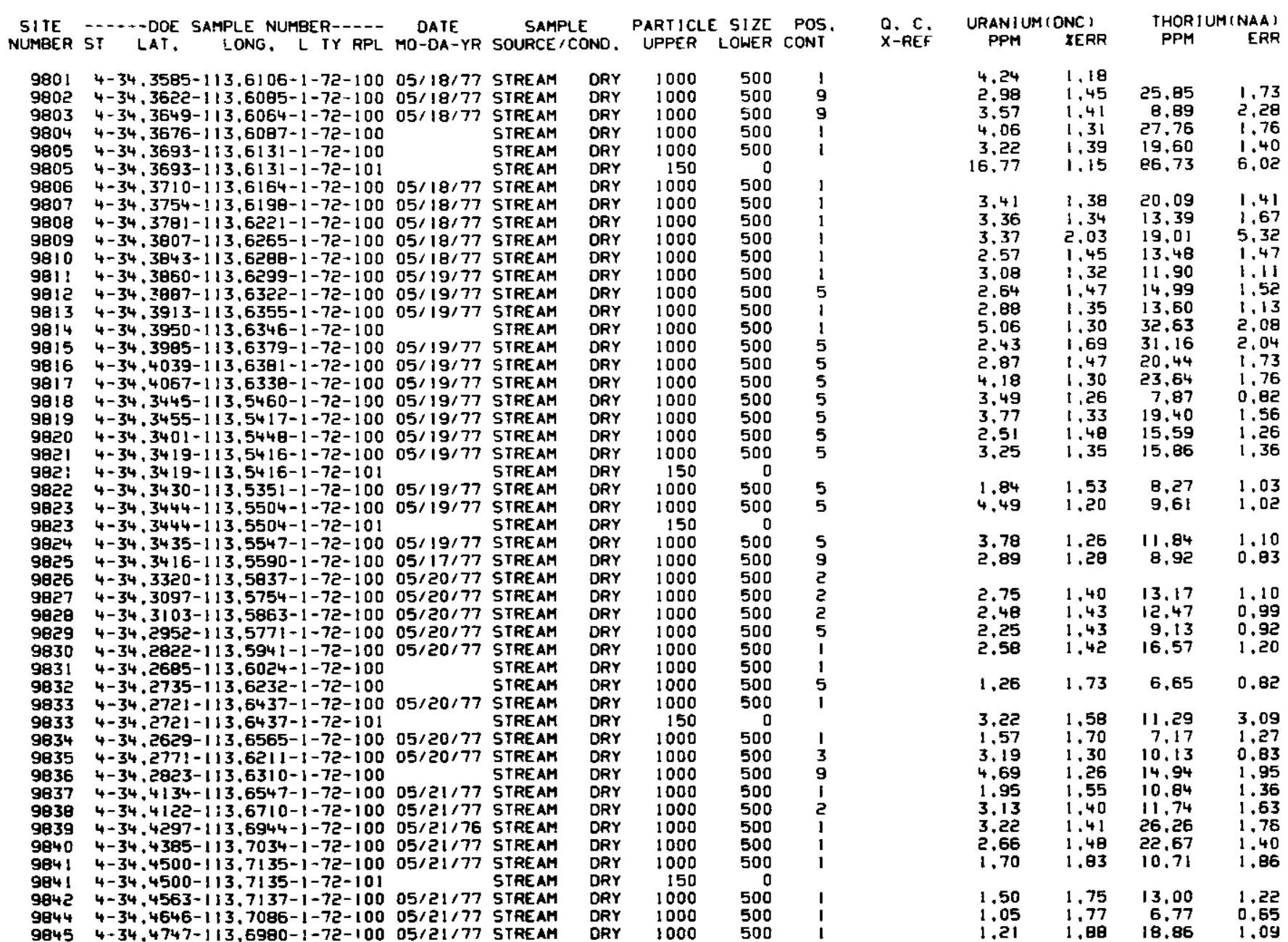




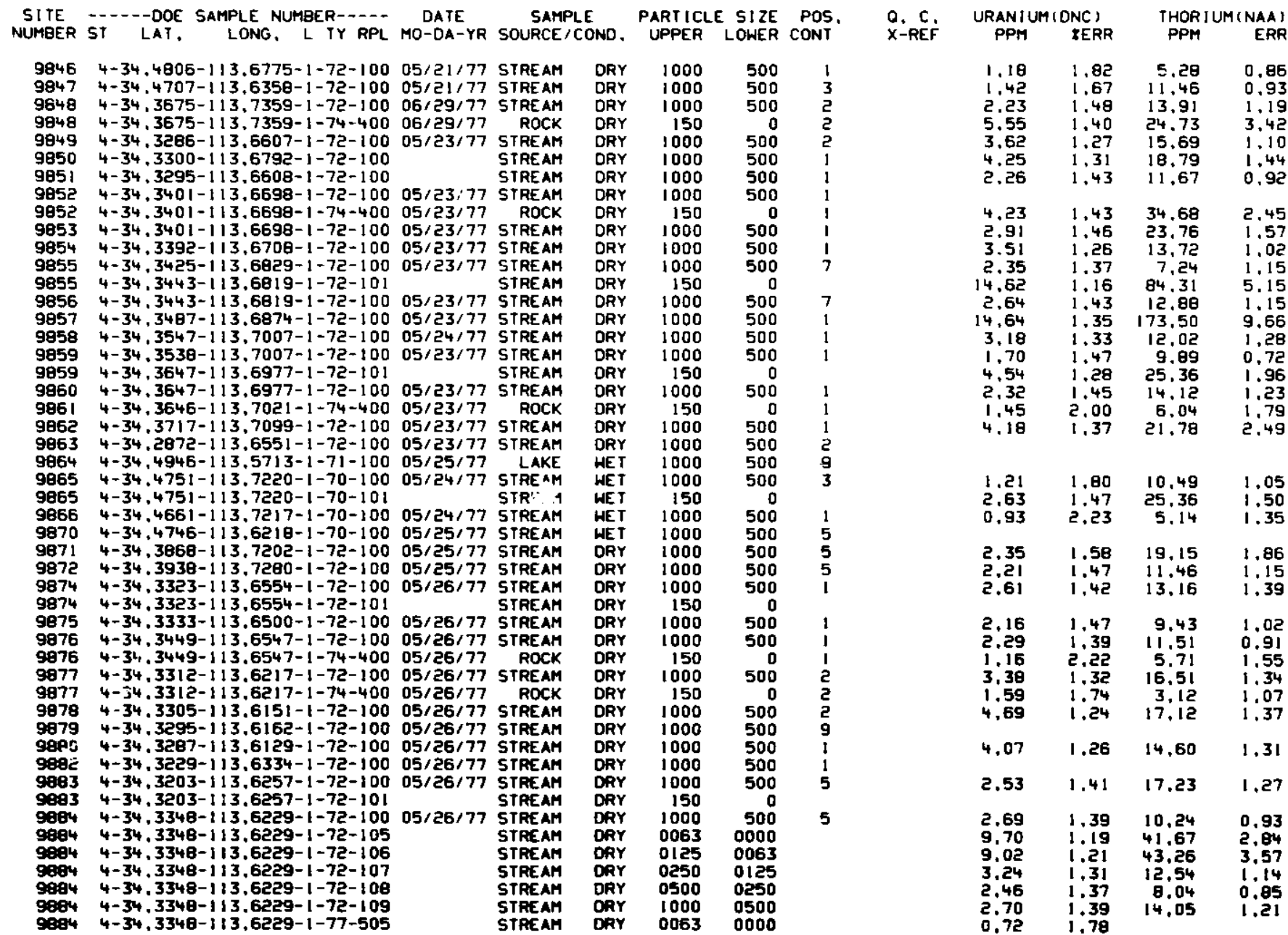




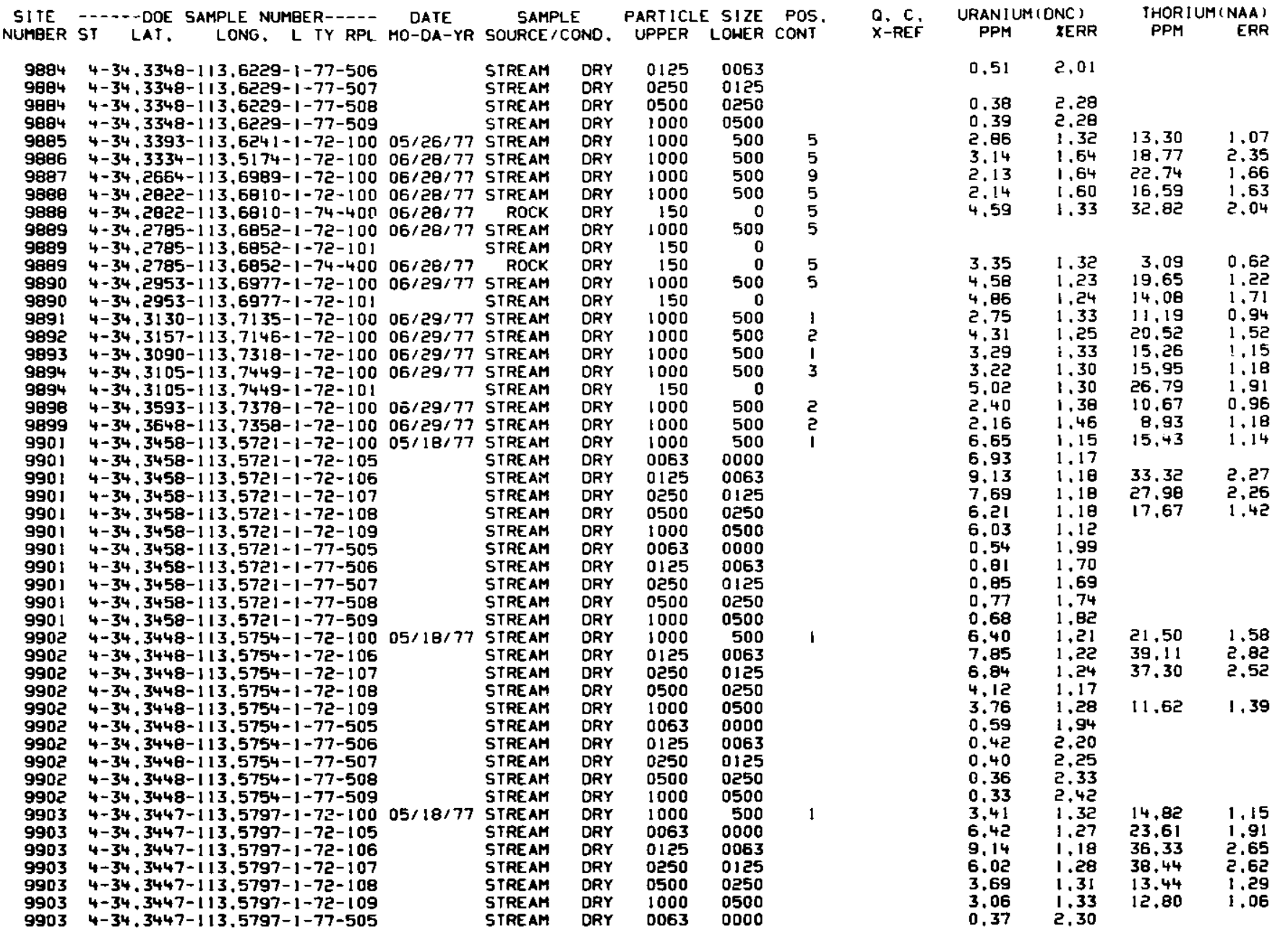




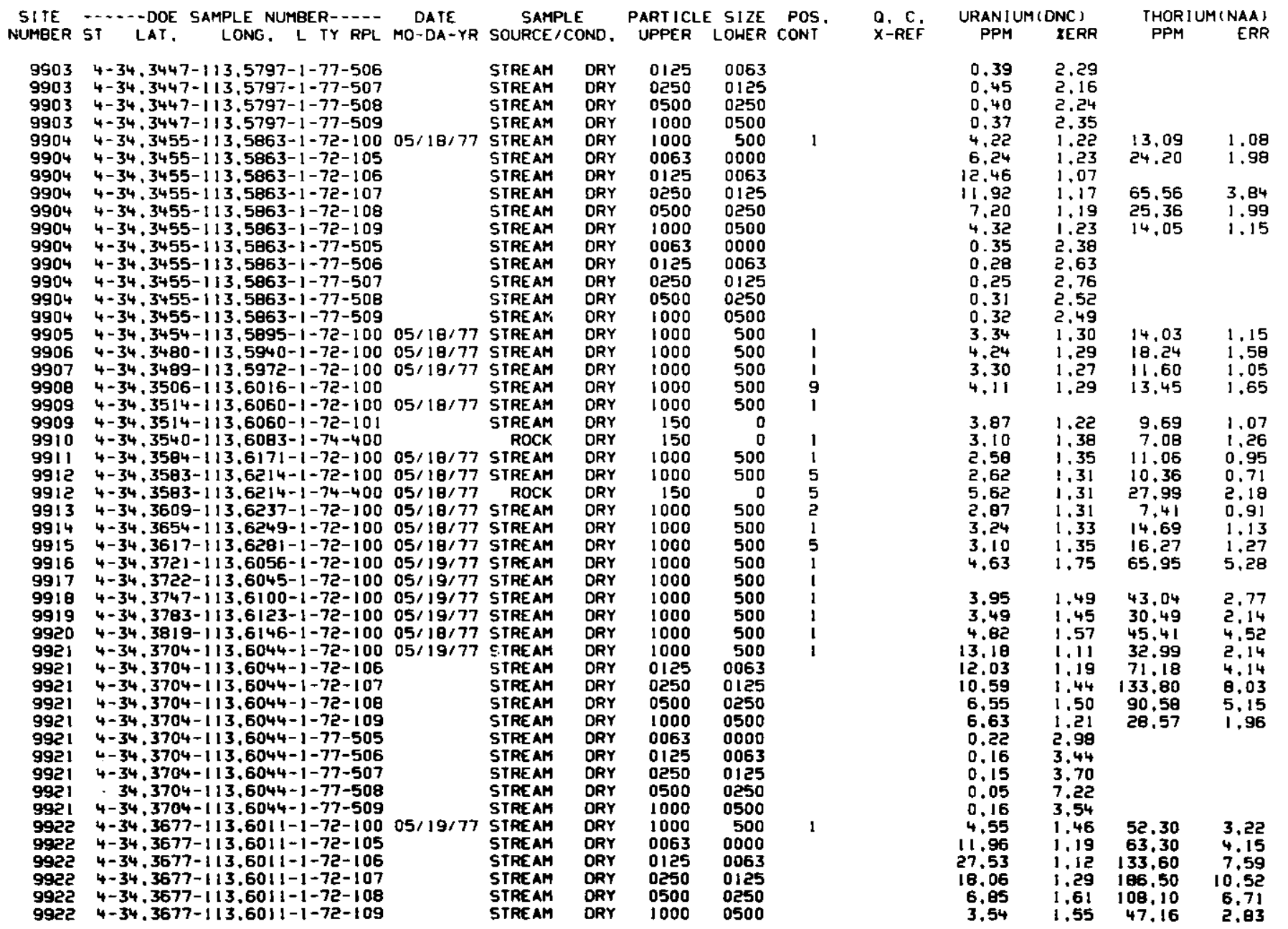




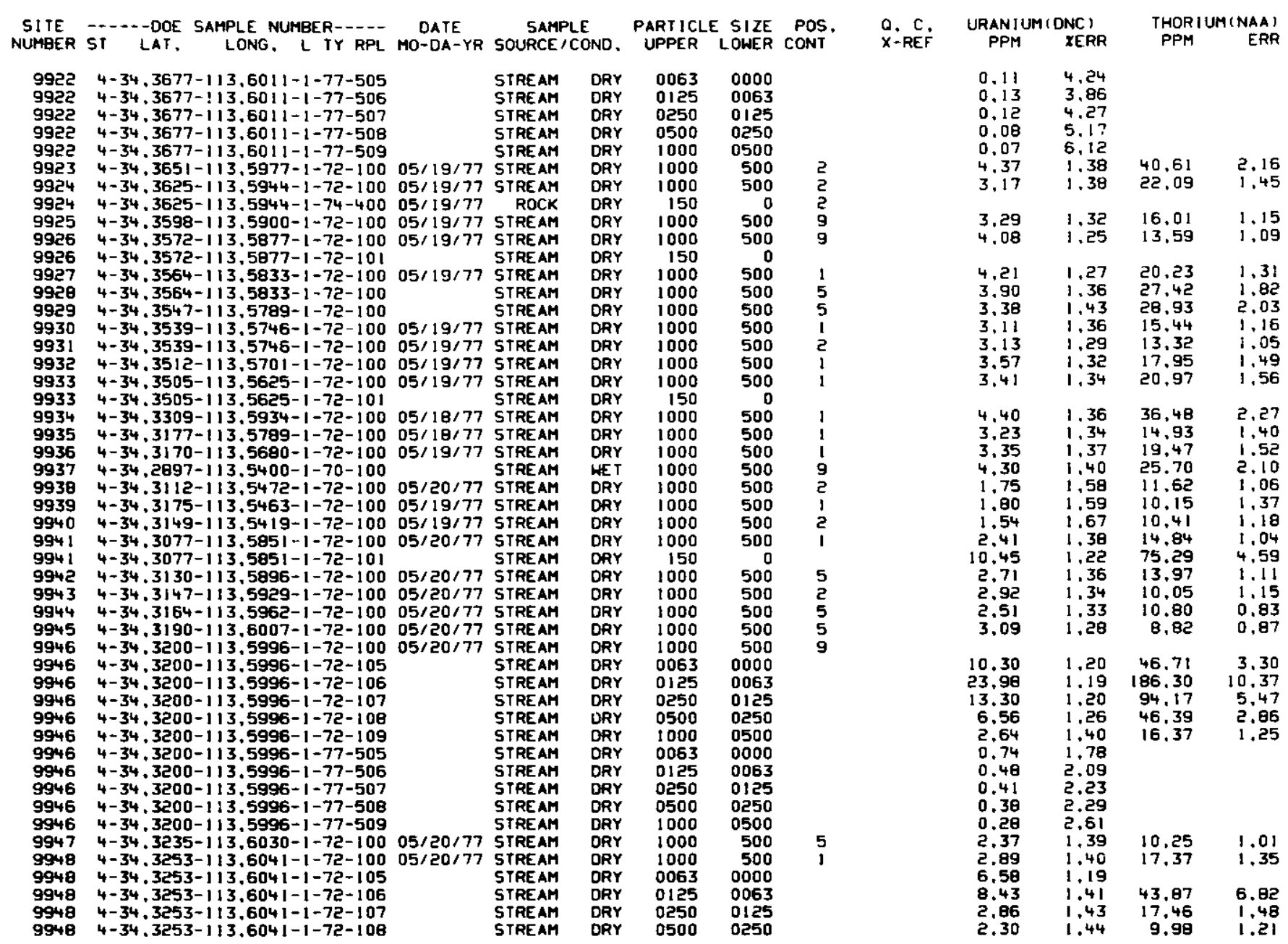




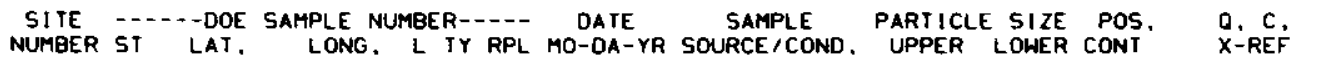
URANIUMIONC;

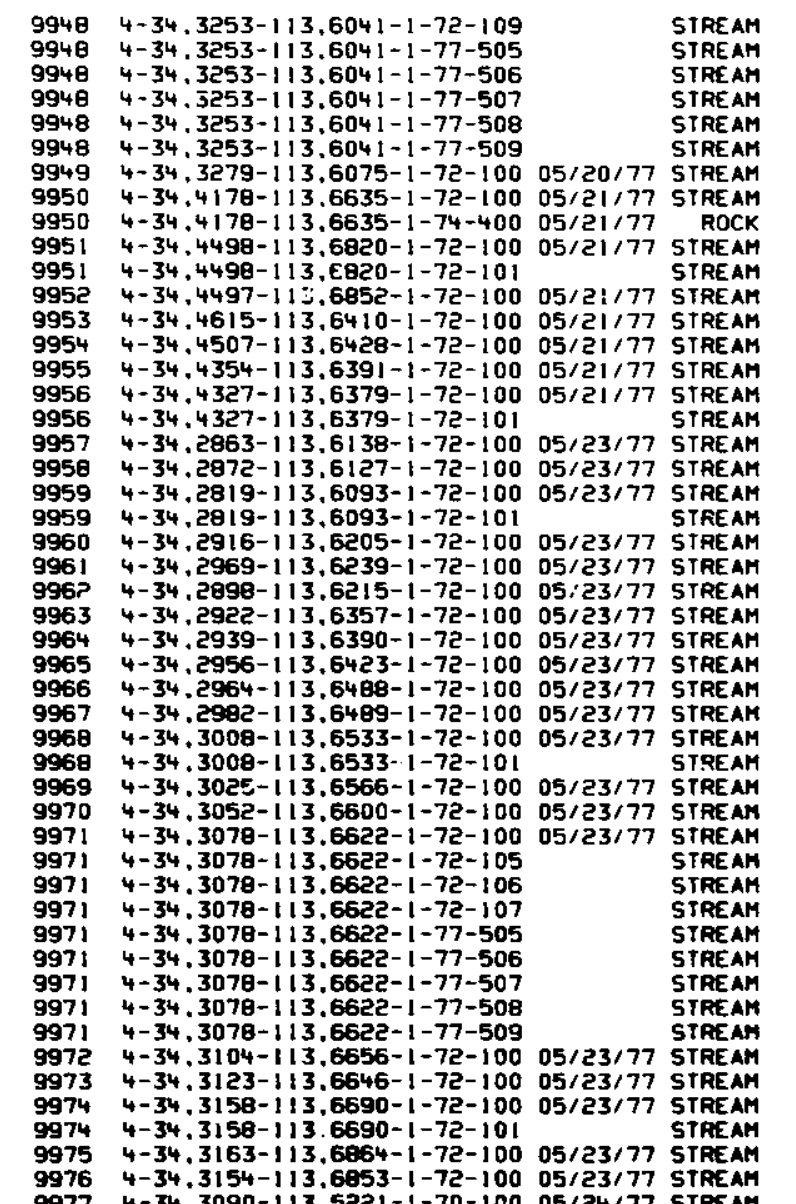

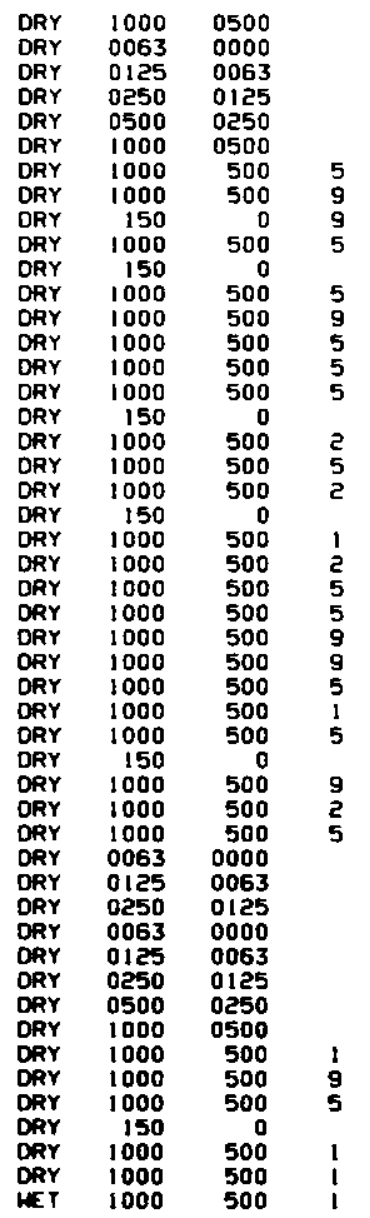




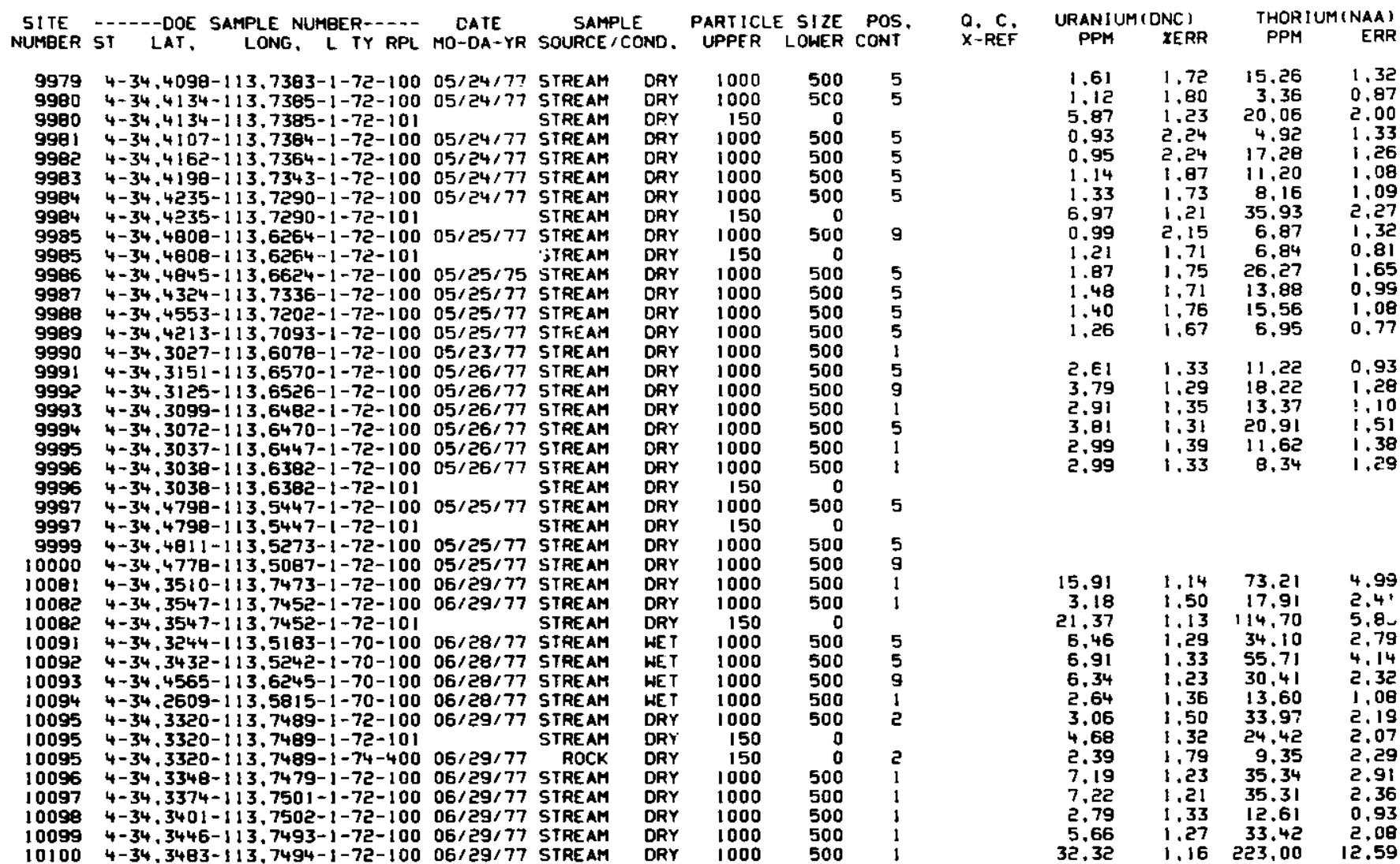





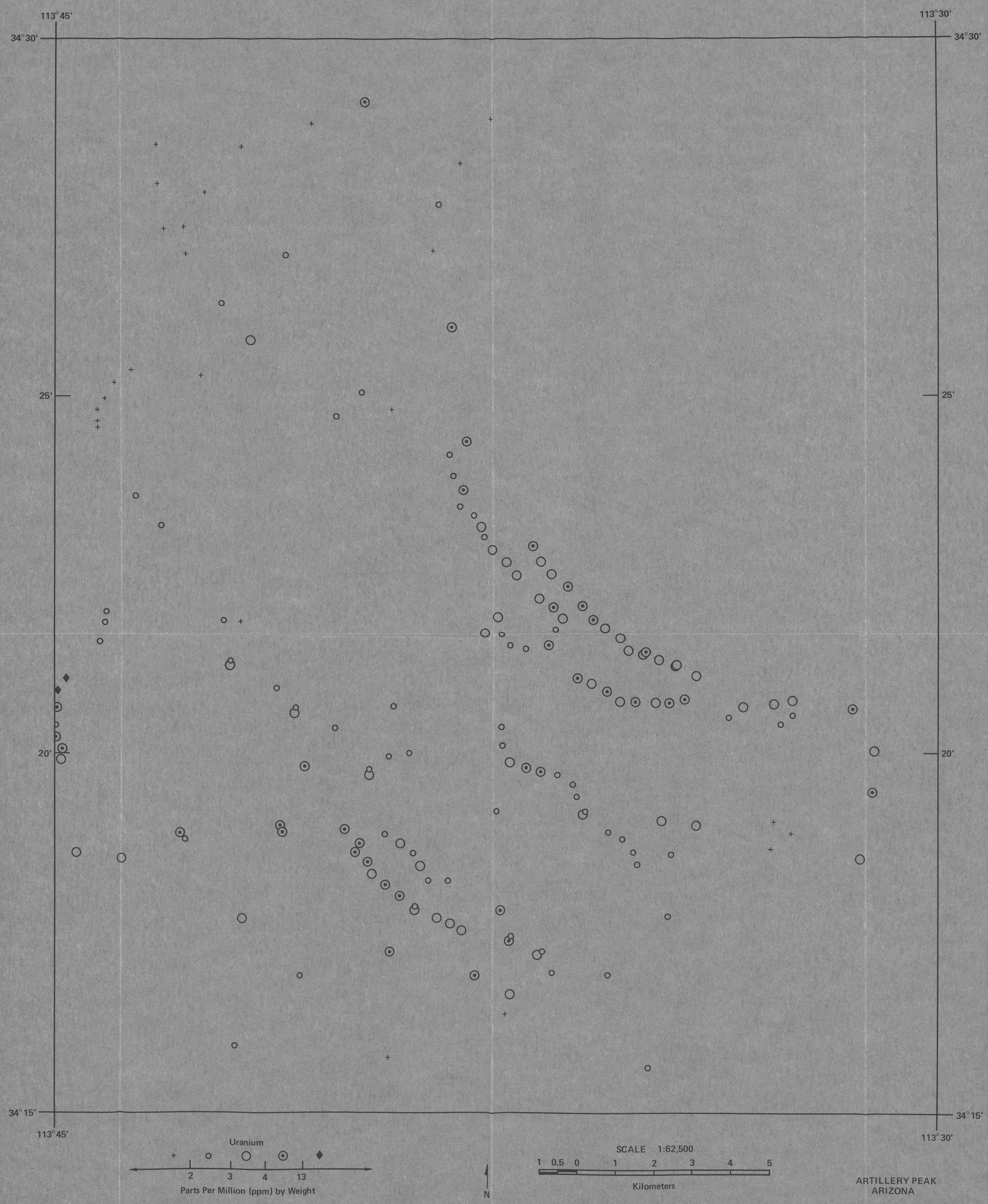





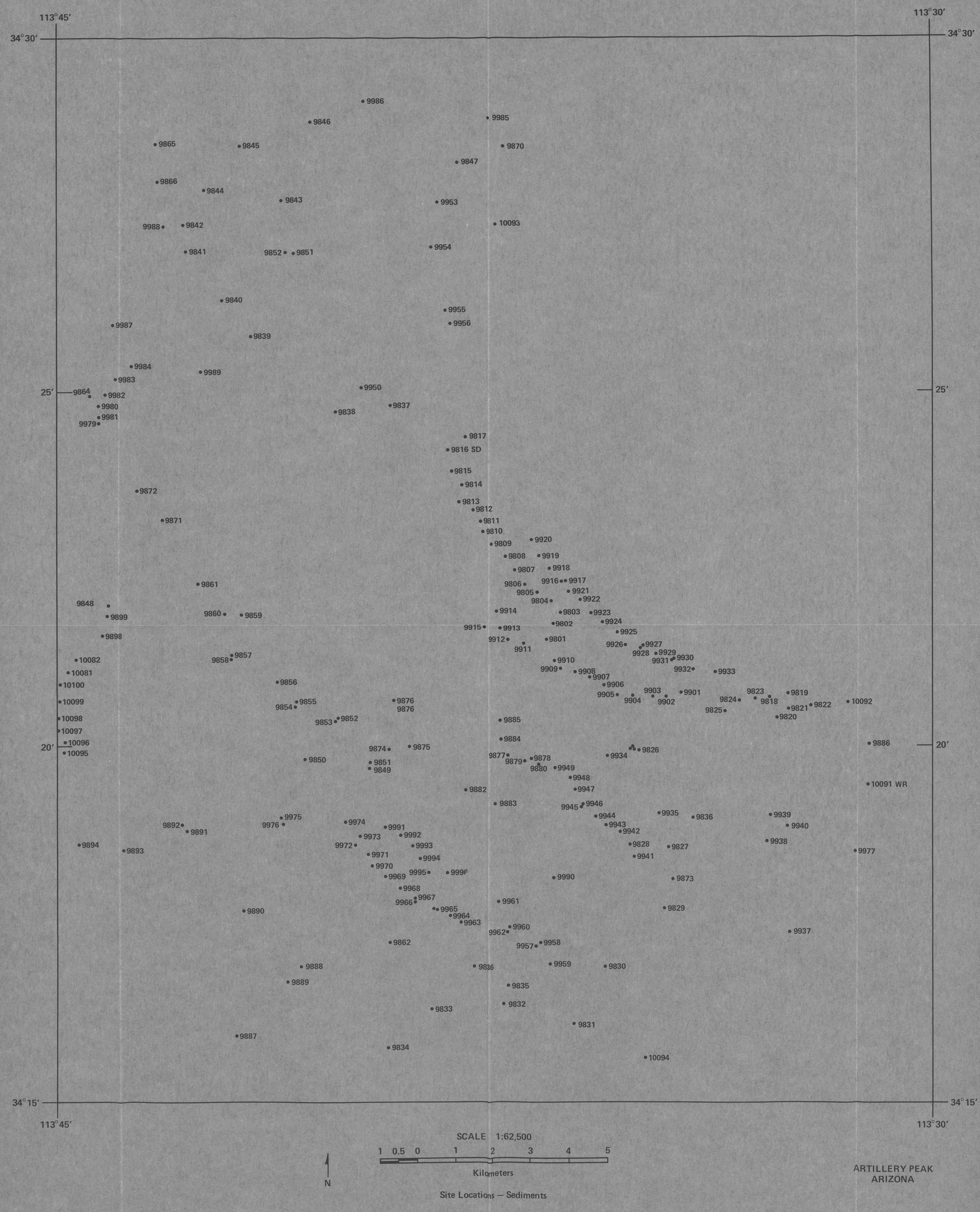






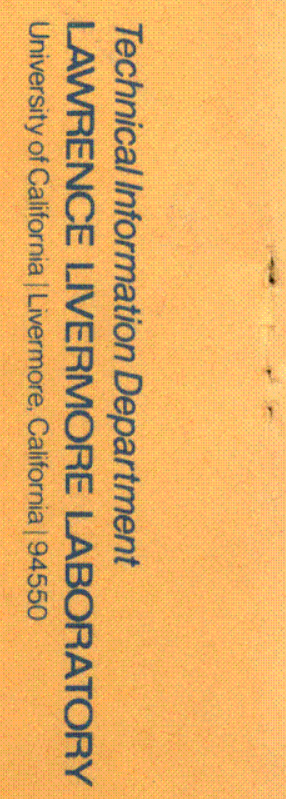

